\title{
Dangyuja (Citrus grandis Osbeck) Peel Improves Lipid Profiles and Alleviates Hypertension in Rats Fed a High-Fat Diet
}

Hyun Ju Hong', Ju Youn Jin', Heekyoung Yang1, Won Young Kang', Dong Geon Kim¹, Sunyi Lee², Younghun $\mathrm{Choi}^{2}$, Jae Hoon Kim${ }^{1}$, Chang Hoon Han' ${ }^{1}$ and Young Jae Lee ${ }^{1 *}$

${ }^{1}$ College of Veterinary Medicine, Jeju National University, Jeju, Korea

${ }^{2}$ Citrus Research Station, National Institute of Horticultural \& Herbal Science, Rural Development Administration, Jeju, Korea

\begin{abstract}
Obesity is a major public health problem and significant risk factor for many serious diseases including coronary artery disease, cancer, and diabetes. This study was performed to investigate the hypolipidemic effects and anti-hypertensive effect of Dangyuja (Citrus grandis Osbeck) peel, which is bred on Jeju island, in rats fed a high-fat diet. This study was conducted on 4 equal rat groups which were fed as follows; normal diet group (ND), high fat diet group (HFD), high fat diet supplemented with powdered peel of Dangyuja (1\%, wt/wt) group (HFD+Dangyuja), and high fat diet treated with sibutramine simultaneously at a dose of $10 \mathrm{mg} / \mathrm{kg}$ group (HFD+Sibutramine). After feeding the high fat diet, body weight gain and relative weight of adipose tissues and liver significantly increased in HFD group, but Dangyuja peel supplementation protected these HFD-induced changes. The levels of serum triglyceride, total cholesterol, low-density lipoprotein (LDL)-cholesterol, and the atherogenic index significantly decreased in the HFD+Dangyuja peel group compared with the HFD group. The systolic blood pressure was significantly increased by feeding the high fat diet, whereas the supplementation of Dangyuja peel effectively prevented the elevation of blood pressure. Therefore, these results suggest that Dangyuja exerts a beneficial effect on obesity by improving lipid metabolism and alleviating obesity-related hypertension.
\end{abstract}

Key words: Dangyuja, high-fat diet, obesity, cholesterol, hypertension

Received 27 August 2010; Revised version received 25 November 2010; Accepted 29 November 2010

비만은 열량섭취와 소비의 불균형으로 인하여 체지방 축적이 야기되는 대사성 질환의 일종으로, 현대 사회의 급속한 비만인구의 증가는 전세계적으로 심각한 사회적 문제가 되고 있다(Kopelman, 2000; Hill et al., 2007). 혈중 콜레스테롤과 low-density lipoprotein-cholesterol (LDL-C)의 농도 증가 및 high-density lipoproteincholesterol $(\mathrm{HDL}-\mathrm{C})$ 의 감소는 비만의 특징적 소견으로, 고 콜레스테롤혈증(hypercholesterolemia)과 고중성지방혈증 (hypertriglyceridemia)이 동반되며, 고혈압, 동맥경화 등 심 혈관계 질환, 지방간 및 당뇨병 등의 질병에 대한 위험 성이 증가하게 된다(Festi et al., 2004). 따라서, 지질대사 의 개선은 비만을 비롯한 여러 질병의 예방 및 치료에 유익한 효과를 줄 것으로 기대되고 있다.

*Corresponding author: Young Jae Lee, College of Veterinary Medicine, Jeju National University, 66 Jejudaehakno, Jeju, Jeju 690-756, Korea

Tel: + 82-64-754-3371

Fax: +82-64-756-3354

E-mail: yjlee3@jejunu.ac.kr
현재 주로 사용되고 있는 비만 치료제인 sibutramine과 orlistat의 경우에도 각각 심혈관계 및 위장관계에 부작용 이 있는 것으로 알려져 있어(Fujioka et al., 2000; McMahon et al., 2000; Leung et al., 2003), 부작용이 없는 항비만치료 약물의 개발이 요구되고 있는 실정이다. 이에 따라 천연물을 대상으로 한 항비만 효능에 대한 많 은 연구가 진행되고 있다. 비만 실험동물 모델에서 Park et al. (2005)은 화살나무(Euonymus alatus)의 지질개선 효 과와 혈당저하 효과를 보고하였고, Nakayama et al. (2007)은 한방약의 항비만 효과를 보고하였다. 또한 Hsu and Yen (2007)은 고지방식이로 유도한 비만 실험동물 모 델에서 나타나는 이상지질혈증(dyslipidemia)과 지방간증 (hepatosteatosis) 및 산화적 스트레스(oxidative stress)에 대 한 gallic acid의 억제 효과를 보고하였다.

한편 제주 자생 감귤류의 일종인 당유자(Citrus grandis Osbeck)는 유기산 및 유리당, 무기질, 비타민 등의 영양 성분, limonin, obacunone, nomilin 등의 limonoid류, naringin, hesperidin 등의 flavonoid류와 같은 다양한 기능 
성 성분을 함유하고 있는 것으로 보고되어 있다(Song et al., 1998; Lee et al., 2006). 최근에는 또한 당유자의 잎 또는 과실 추출물의 항산화 효과 및 염증억제 효과, 위 암억제효과 등 다양한 생리활성이 보고되었다(Lee et al., 2006; Lim et al., 2006; Moon et al., 2009).

따라서, 본 연구에서는 당유자의 항비만 효과를 확인하 기 위하여 고지방 식이로 비만을 유도한 Sprague-Dawley (SD) 랫드에서 당유자 과피의 지질대사 및 비만에 따른 혈압 변화에 미치는 영향에 대하여 연구하였다.

\section{재료 및 방법}

\section{실험동물}

$\mathrm{SD}$ 계 수컷 랫드(4주령; $80 \mathrm{~g}$ )를 (주)오리엔트바이오 (Seongnam, Gyeonggi, Korea)로부터 구입하여 1주간 제주 대학교 실험동물사육실 환경에 순화시킨 후 실험에 사용 하였고, 실험 동물 사육실 환경은 온도 $23 \pm 2^{\circ} \mathrm{C}$, 상대습 도 $50 \pm 10 \%$ 이었으며, 명암주기는 12 시간 단위로 조절되 었다. 모든 실험동물은 살균 소독된 wire drop bottom cage에 한 마리씩 사육되었고, 물은 멸균 하지 않은 수 도물을 사용하였으며 물과 사료는 자유섭취시켰다.

본 연구에서의 모든 동물실험은 제주대학교 동물실험 윤리위원회(Animal Care and Use Committee, ACUCC) 의 승인 하에 수행되었다.

\section{실험식이 조성 및 급여}

지질대사 개선 효과에 대한 실험군은 기본식이를 공급 한 정상식이군(normal diet; $\mathrm{ND}, \mathrm{n}=5$ ), 고지방식이 대조 군(high-fat diet; HFD, $\mathrm{n}=5$ ), 당유자 과피가 혼합된 고지 방식이 공급군(HFD+Dangyuja, $\mathrm{n}=5)$, 고지방식이와 sibutramine 병행 공급군(HFD+Sibutramine, $n=5)$ 으로 나 누었다. 기본식이는 5L79 (LabDiet, Charles River, Wilmington, MA, USA)를 급여하였고 비만을 유도하기 위 한 고지방사료로 AIN-76A (TestDiet ${ }^{\mathbb{}}$, Dyets, Bethlehem, $\mathrm{PA}, \mathrm{USA}$ )에 우지를 40\%되게 혼합한 Dyets\#101556를 (주)중앙실험동물(Seoul, Korea)에서 구입하여 급여하였다.

실험에 사용한 당유자는 제주도 농촌진흥청 국립원예 특작과학원 감귤시험장(Seogwipo, Korea)에서 제공받아 사 용하였다. 과피를 분리 및 분쇄한 후 고지방사료에 $1 \%$ 되게 혼합하여 10 주간 급여하였고, 양성 대조군으로 사 용한 Sibutramine (DaeHe Chemical Co., Ltd., Shihung, Gyeonggi, Korea) 은 $10 \mathrm{mg} / \mathrm{kg}$ 의 농도로 10 주 동안 매일 오전 10시에 한번씩 경구투여하였다.

\section{체중변화, 사료섭취량 및 사료효율 측정}

체중 측정은 실험시작 전 및 투여기간 중 매주 1회 오
전 11시에 이루어졌고, 최종 체중에서 실험 개시 전의 체 중을 감하여 체중 증가량을 구하였다. 사료섭취량은 매주 2회씩 측정하였다. 각 실험군의 사료효율을 총 사료섭취 량에 대한 전 실험기간 동안의 증체량의 비율로 산출하 였다.

\section{혈압 측정}

실험 종료 후, 모든 실험동물의 수축기 혈압을 Power lab 혈압 측정기를 이용하여 마취 없이 tail cuff method (Cuevas et al., 1996)로 측정하였다. Tail cuff와 pulse transducer는 MLT1050 (AD Instrument, Mountain View, CA, USA)을 사용하였으며, Chart 5 for Windows (AD Instrument)로 혈압을 분석하였다.

\section{실험동물의 처리}

10 주간의 실험 종료 후, 모든 실험동물을 18 시간 동안 절식시킨 후 $\mathrm{CO}_{2}$ 로 안락사시켰다. 실험동물의 복부둘레 를 줄자를 이용하여 측정하였고, 복대정맥으로부터 채혈 한 후, $3,000 \mathrm{rpm}$ 에서 10 분간 원심분리 하여 얻은 혈청 에서 지질 함량을 측정하였다. 그리고 간과 고환, 부고환 지방 및 복부 지방을 적출하여 생리식염수로 혈액을 제 거한 후 수분을 제거하고 중량을 측정하였으며, 체중에 대한 상대중량비를 구하였다. 상대중량(\%)은 (장기중량/체 중)*100으로 산출하였다.

\section{혈청 내 지질 함량 측정}

혈청 중 중성지질(triglyceride; TG), 총콜레스테롤(total cholesterol; TC), HDL-C의 함량을 혈청생화학자동분석기 (PRONTO EVOLUTION, BPC, Bio SED S.R.L, Rome, Italy)를 사용하여 측정하였다. 혈청 내 LDL-C의 함량은 정량된 TC 함량에서 $\mathrm{HDL}-\mathrm{C}$ 의 함량을 감하여 산출하였 고, LDL-C 함량을 HDL-C 함량으로 나누어 동맥경화지수 (atherogenic index)를 구하였다.

\section{간조직의 지질 과산화물 함량 측정}

간조직 내의 지질 과산화물 함량은 Buege and Aust (1978)의 방법에 따라 thiobarbituric acid (TBA)법을 이용 하여 생성된 TBA-reactive substances (TBARS), 즉 malondialdehyde (MDA)의 양을 $532 \mathrm{~nm}$ 에서 측정하여 단 백질 $\mathrm{mg}$ 당으로 나타내었다.

\section{조직병리학적 관찰}

간조직 내 지질 침착 정도를 관찰하기 위하여 중량측 정 후 $10 \%$ 중성 포르말린 용액에 고정시켰다. 통상적인 파라핀 포매 후 $4 \mu \mathrm{m}$ 두께로 절편을 만들어 hematoxylin \& eosin (H\&E) 염색하여 광학현미경으로 관찰하였다. 
Table 1. Effects of peel of Dangyuja on body weight, food intake and food efficiency ratio (FER) of high-fat diet-fed rats

\begin{tabular}{lccc}
\hline \multicolumn{1}{c}{ Groups } & Weight gain $(\mathrm{g})$ & Food intake $(\mathrm{g} /$ day $)$ & FER \\
\hline ND & $380.9 \pm 11.6$ & $30.7 \pm 1.3$ & $0.18 \pm 0.01$ \\
HFD & $483.2 \pm 15.8^{++}$ & $18.5 \pm 0.7^{+++}$ & $0.36 \pm 0.00^{+++}$ \\
HFD+Dangyuja & $449.8 \pm 25.8$ & $19.3 \pm 0.7^{+++}$ & $0.35 \pm 0.01^{+++}$ \\
HFD+Sibutramine & $372.5 \pm 15.0^{* *}$ & $14.8 \pm 0.9^{+++++}$ & $0.33 \pm 0.01^{+++}$ \\
\hline
\end{tabular}

ND; rats fed normal diet for 10 weeks, HFD; rats fed high-fat diet for 10 weeks, HFD+Dangyuja; rats fed-high fat diet supplemented with $1 \%$ of Dangyuja peel for 10 weeks, HFD+Sibutramine; rats fed high-fat diet supplemented with $10 \mathrm{mg} / \mathrm{kg}$ of sibutramine $.{ }^{++} P<0.01$, ${ }^{+++} P<0.001$ compared to ND group. ${ }^{* *} P<0.01,{ }^{* * *} P<0.001$ compared to HFD group.

\section{통계처리}

실험 결과는 SPSS 12.0K for Windows (Release 12.0.0, SPSS Inc., USA)를 사용하여 통계처리 하였으며, 모든 결 과는 평균과 표준오차(mean $\pm \mathrm{SE}$ 로 나타내었다. 실험군 간 의 통계 분석은 one-way ANOVA에서 유의성이 인정되 는 경우 LSD test를 통해 실시하였다.

\section{결 과}

\section{체중 및 사료섭취량에 미치는 영향}

정상군(ND)의 체중은 10 주 동안의 실험기간 동안
$380.9 \pm 11.6 \mathrm{~g}$ 의 체중 증가를 보였고, 이에 비해 고지방사 료 식이군(HFD)의 체중은 $\mathrm{ND}$ 군에 비해 약 $26.9 \%$ 증가 한 $483.2 \pm 15.8 \mathrm{~g}$ 의 체중 증가를 보여 고지방사료 공급으 로 체중이 유의적으로 증가함을 확인하였다(Table 1). 당 유자 과피가 혼합된 고지방식이 공급군(HFD+Dangyuja) 및 고지방식이와 sibutramine 병행 공급군(HFD+ Sibutramine)의 체중은 각각 $449.8 \pm 25.8,372.5 \pm 15.0 \mathrm{~g}$ 증 가함으로써 $\mathrm{HFD}$ 군과 비교하여 각각 $6.9,22.9 \%$ 의 체중 감소를 보였다. 고지방식이로 사료섭취량(18.5 $\pm 0.7 \mathrm{~g} /$ day) 은 감소되었지만 $\mathrm{HFD}$ 군의 사료효율 $(0.36 \pm 0.00)$ 은 $\mathrm{ND}$ 군 에 비하여 2배 가량 증가하였고, HFD+Dangyuja군에서
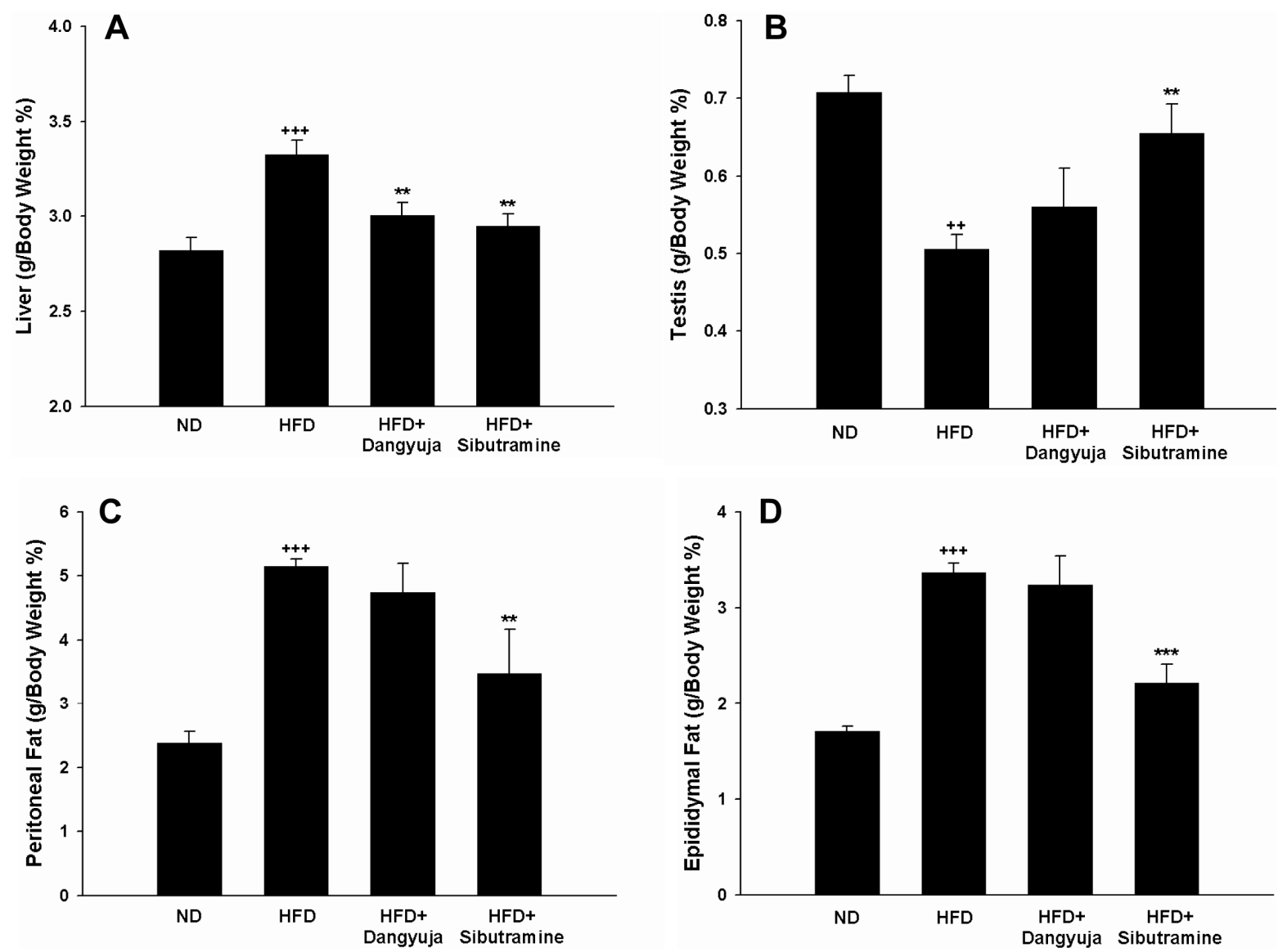

Figure 1. Effects of peel of Dangyuja on relative organ and fat weights of high-fat diet (HFD)-fed rats. ${ }^{++} P<0.01,{ }^{+++} P<0.001$ compared to normal diet (ND) group. ${ }^{* *} P<0.01,{ }^{* * *} P<0.001$ compared to HFD group. 

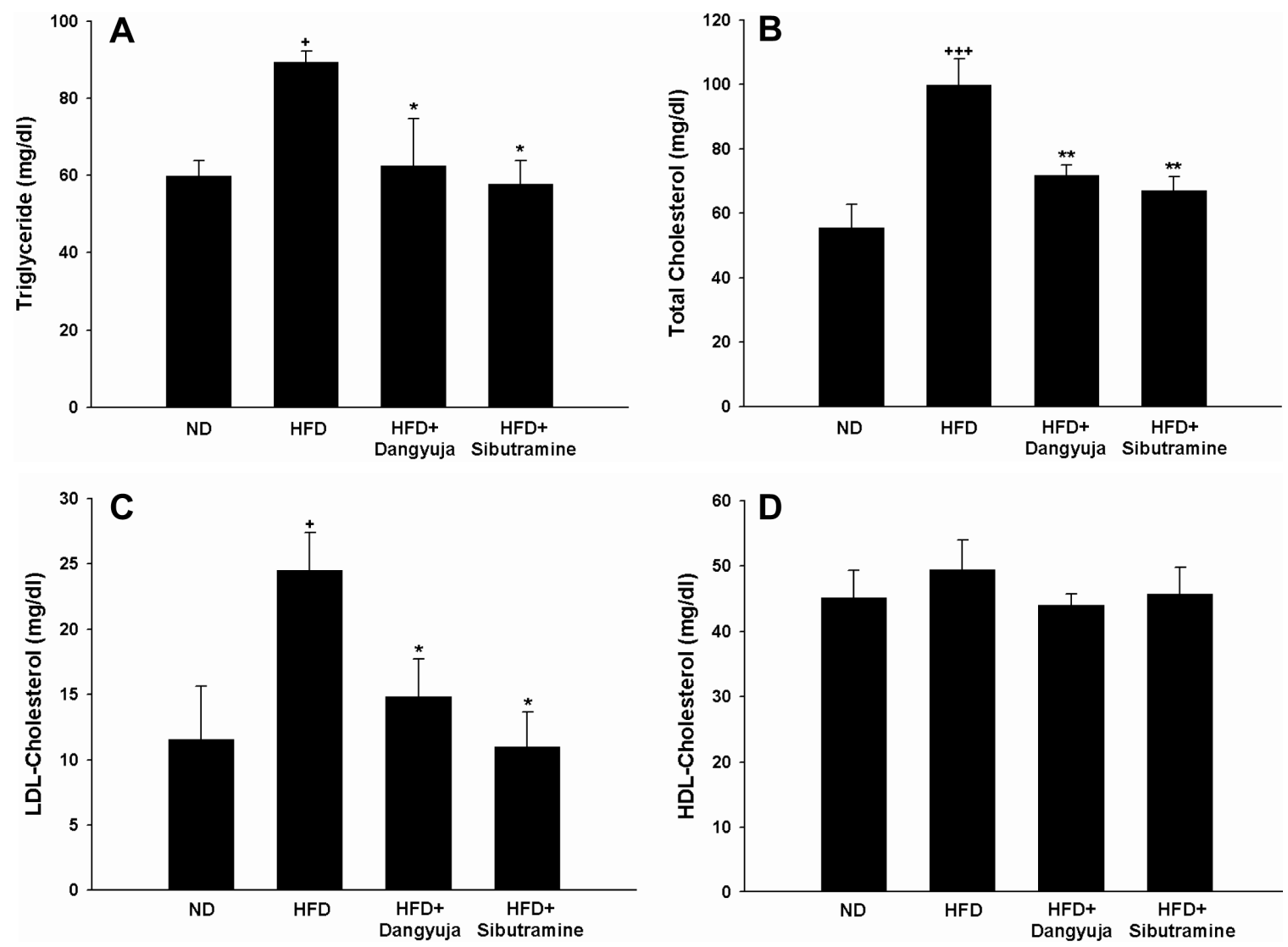

Figure 2. Effects of peel of Dangyuja on serum lipid contents of high-fat diet (HFD)-fed rats. LDL; low-density lipoprotein, HDL; high-density lipoprotein. ${ }^{+} P<0.05,{ }^{+++} P<0.001$ compared to normal diet (ND) group. ${ }^{*} P<0.05,{ }^{* *} P<0.01$ compared to HFD group.

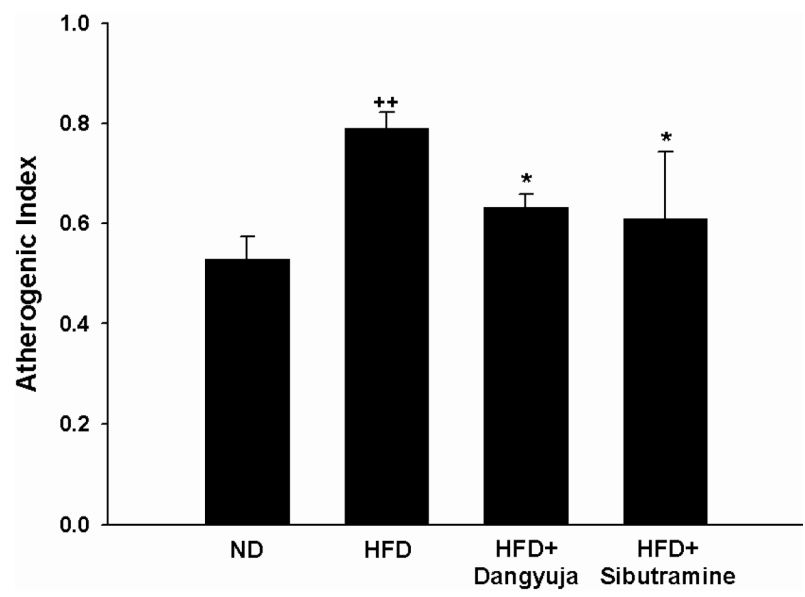

Figure 3. Effect of peel of Dangyuja on atherogenic index of high-fat diet (HFD)-fed rats. ${ }^{++} P<0.01$ compared to normal diet (ND) group. ${ }^{*} P<0.05$ compared to HFD group.

도 비슷한 사료섭취량( $19.3 \pm 0.7 \mathrm{~g} / \mathrm{day})$ 및 사료효율 (0.35 \pm 0.01$)$ 을 나타내었다. 반면, HFD+Sibutramine군에서 는 사료섭취량 $(14.8 \pm 0.9 \mathrm{~g} / \mathrm{day})$ 이 유의적으로 감소하였고 체중 역시 감소함에 따라 사료효율은 HFD군 또는 HFD+Dangyuja군과 유사하게 나타났다.

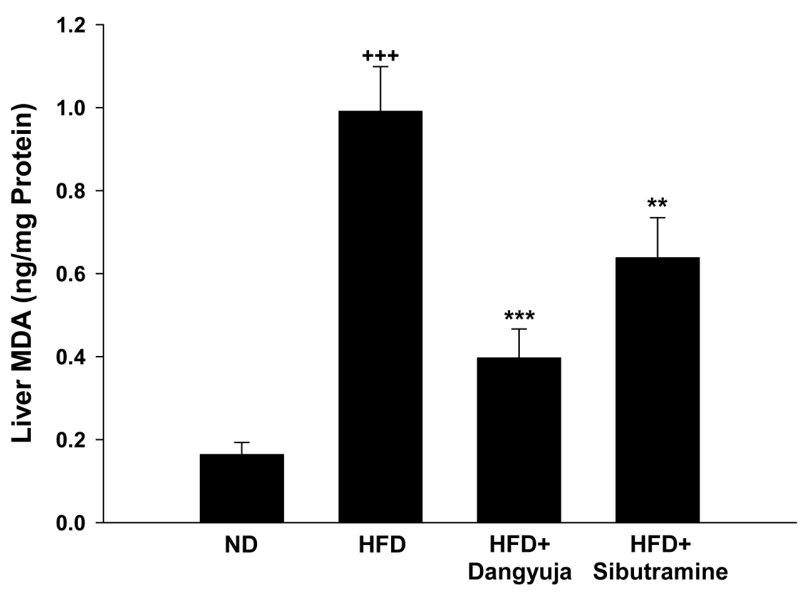

Figure 4. Effect of peel of Dangyuja on hepatic malondialdehyde (MDA) level of high-fat diet (HFD)-fed rats. ${ }^{+++} P<0.001$ compared to normal diet (ND) group. ${ }^{\star *} P<0.01$, ${ }^{* \star *} P<0.001$ compared to HFD group.

\section{장기중량 및 지방조직 중량에 대한 영향}

간과 복부지방 및 부고환지방의 무게를 체중에 대한 비 율로 산출한 결과, $\mathrm{HFD}$ 군에서 $\mathrm{ND}$ 군에 비해 유의적으로 증가하였고, 당유자 과피가 혼합된 HFD+Dangyuja군 및

Lab. Anim. Res. | December, 2010 | Vol. 26, No. 4 


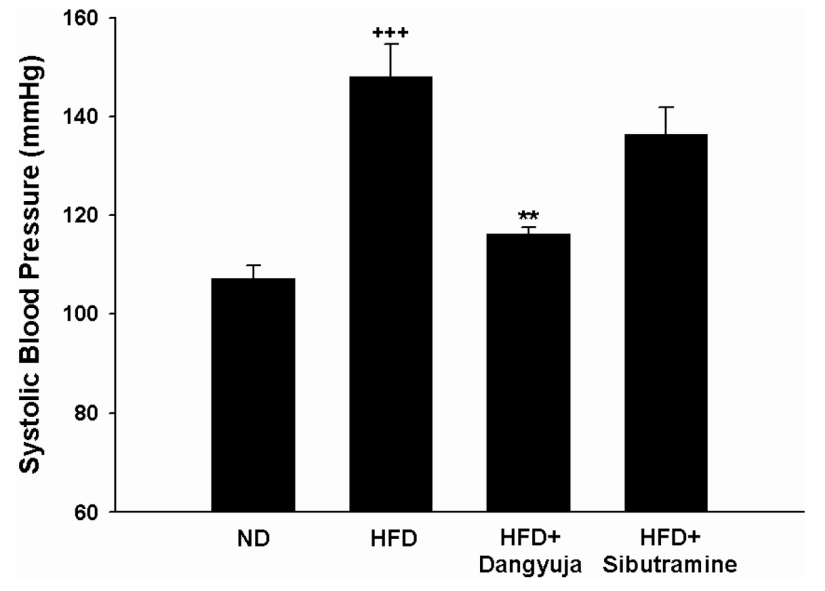

Figure 5. Effect of peel of Dangyuja on systolic blood pressure of high-fat diet (HFD)-fed rats. ${ }^{++} P<0.001$ compared to normal diet (ND) group. ${ }^{* *} \mathrm{P}<0.01$ compared to HFD group.

HFD+Sibutramine군에서는 HFD군에 비해 감소하였다 (Figure 1). 반면 $\mathrm{ND}$ 군에 비해 $\mathrm{HFD}$ 군에서 감소한 체중 당 고환의 무게 비율은 HFD+Dangyuja군 및 HFD+ Sibutramine군에서 증가하였다.

\section{혈청 내 지질 함량에 미치는 영향}

$\mathrm{ND}$ 군의 혈청 내 $\mathrm{TG}, \mathrm{TC}$ 및 $\mathrm{LDL}-\mathrm{C}$ 의 함량이 각각
$55.90 \pm 3.91,55.55 \pm 7.20$ 및 $11.56 \pm 4.08 \mathrm{mg} / \mathrm{d}$ 인 것에 비 해 10 주간 고지방 사료를 식이한 $\mathrm{HFD}$ 군에서는 각각 $89.36 \pm 2.88,99.93 \pm 7.97$ 및 $24.48 \pm 2.92 \mathrm{mg} / \mathrm{dl}$ 의 수준으로 나타나 유의적으로 혈청 내 지질 함량이 증가하였다(Figure 2). $\mathrm{HFD}+$ Dangyuja군에서는 $\mathrm{TG}, \mathrm{TC}, \mathrm{LDL}-\mathrm{C}$ 이 각각 $62.54 \pm 12.14,71.85 \pm 3.1514 .84 \pm 2.87 \mathrm{mg} / \mathrm{dl}$ 으로 HFD군 의 혈청 내 지질함량과 비교하여 유의적인 감소를 보였 고, $\mathrm{HFD}+$ Sibutramine군에서도 각각 $57.80 \pm 6.08,67.18 \pm$ $4.32,11.03 \pm 2.65 \mathrm{mg} / \mathrm{dl}$ 으로 HFD군의 혈청 내 지질함량 과 비교하여 유의적인 감소를 보였다. 반면 혈청 내 $\mathrm{HDL}-$ $\mathrm{C}$ 의 함량은 실험군 간의 차이가 나타나지 않았다.

동맥경화지수를 산출하여 비교한 결과, HFD군 $(0.79 \pm$ $0.03)$ 에서 $\mathrm{ND}$ 군 $(0.53 \pm 0.05)$ 에 비하여 동맥경화지수가 증 가하였고 HFD+Dangyuja군 $(0.63 \pm 0.02)$ 및 HFD+Sibutramine 군(0.61 \pm 0.13$)$ 에서 유의적으로 감소하였다(Figure 3).

\section{간조직의 지질 과산화물 함량에 미치는 영향}

$\mathrm{HFD}$ 군의 간에서 $\mathrm{MDA}$ 의 함량이 $0.99 \pm 0.11 \mathrm{ng} / \mathrm{mg}$ protein으로 $0.16 \pm 0.03 \mathrm{ng} / \mathrm{mg}$ protein인 ND군에 비하여 유의적으로 증가하였다(Figure 4). 이러한 $\mathrm{MDA}$ 의 상승은 HFD+Dangyuja군 및 HFD+Sibutramine군에서 각각 $0.40 \pm 0.07$ 과 $0.64 \pm 0.10 \mathrm{ng} / \mathrm{mg}$ protein으로 HFD군에 비해 유의적인 감소를 보였다.
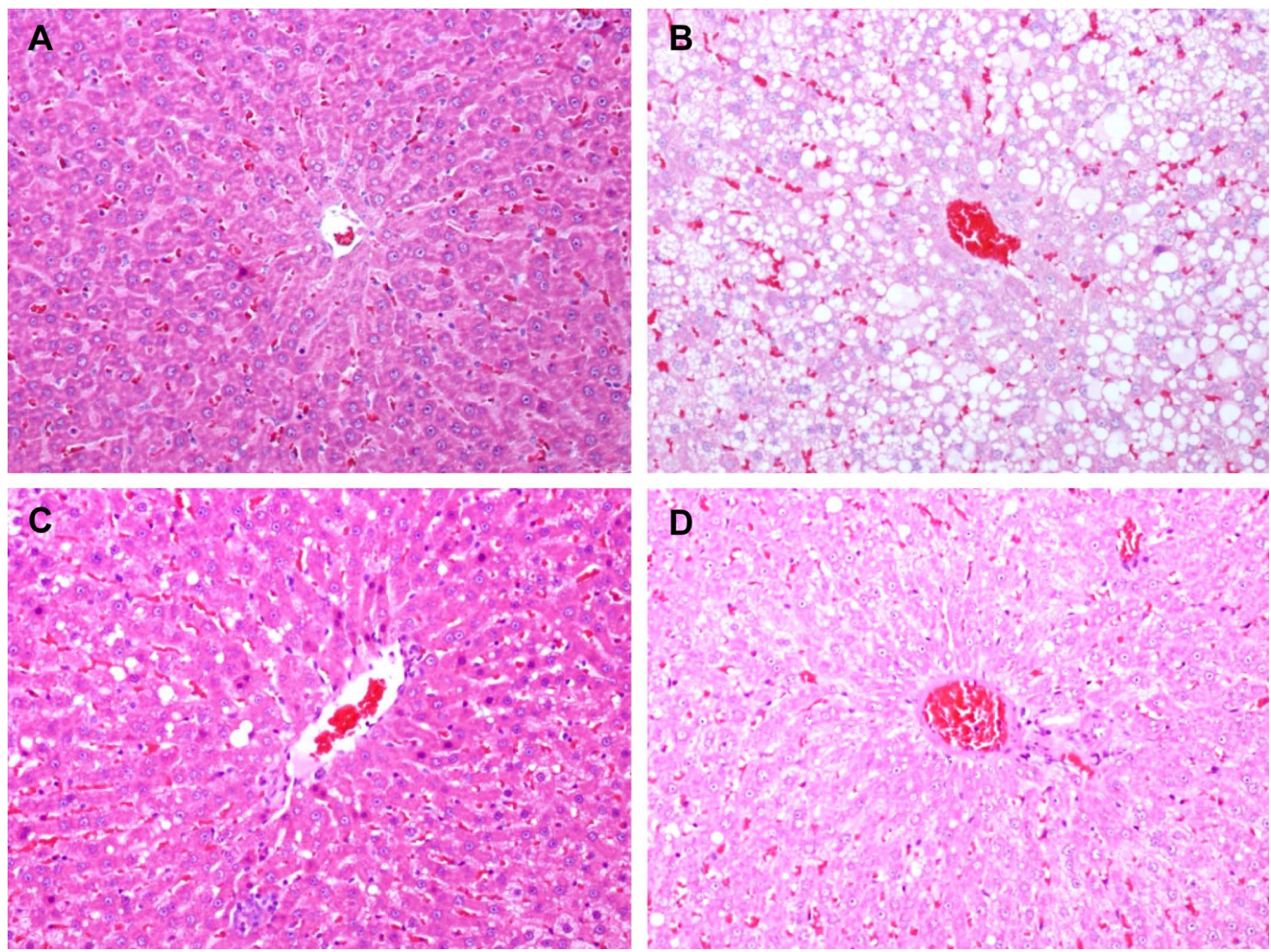

Figure 6. Effect of peel of Dangyuja on accumulation of lipid droplets in the liver of high-fat diet (HFD)-fed rats. A; normal diet group, B; HFD group, C; HFD+Dangyuja, D; HFD+Sibutramine. Original magnification=X200. 


\section{혈압에 미치는 영향}

$\mathrm{HFD}$ 군은 10 주간의 고지방사료 식이로 인해 수축기 혈 압이 $\mathrm{ND}$ 군 $(107.27 \pm 2.56 \mathrm{mmHg})$ 에 비하여 약 $38.3 \%$ 상 승하여 $148.15 \pm 6.54 \mathrm{mmHg}$ 의 유의적인 증가를 보였고, HFD+Dangyuja군(116.20 $1.35 \mathrm{mmHg}$ ) 및 HFD+Sibutramine군(136.46 $\pm 5.39 \mathrm{mmHg}$ 은 $\mathrm{HFD}$ 군에 비해 각각 $21.6 \%$ 와 $8.1 \%$ 혈압이 감소하였다(Figure 5).

\section{조직병리학적 관찰}

간조직을 검사한 결과, $\mathrm{ND}$ 군에서는 이상소견이 관찰되 지 않았고, 이에 비하여 HFD군에서는 간조직 내에 크고 작은 지방방울(lipid droplets)이 전체적으로 산재하여 있었 다(Figure 6). 반면 HFD+Dangyuja군에서는 ND군과 유사 하게 간조직 내 지방축적이 크게 줄어들었으며, $\mathrm{HFD}+$ Sibutramine군에서도 HFD군에 비해 간조직 내 지방축적 이 줄어들었다.

\section{고 찰}

국내에서 서구적인 식생활 패턴과 생활의 편리화가 급 속히 진행됨에 따라 비만인구가 날로 증가하고 그에 따른 고혈압, 동맥경화, 고지혈증, 당뇨병 등의 대사성 질환의 발생이 증가하고 있다. 따라서 이들의 치료에 대한 관심 이 집중되고 있고 비만치료제 또는 기능성식품 소재의 대 사질환 개선효능을 평가하기 위해 동물을 이용한 다양한 식이성 비만모델이 개발되고 있다. 그 중, 고지방식이로 유도한 비만 모델은 여러 연구를 통해 내장 지방 축적, 고 혈당, 지질이상증(dyslipidemia), 고인슐린혈증, 지방간 등 인체 비만의 표현형을 가장 잘 나타내는 것으로 알려져 있으며, 체중 조절이나 비만기전 연구에 적합한 모델로 알 려져 있다(Cho et al., 2005; Vasselli et al., 2005; Kim et al., 2008). 따라서, 본 연구에서는 SD계 랫드에서 고지 방식이로 비만을 유도하여 고지혈증 및 고혈압을 유발하 였고, 이에 대한 당유자 과피의 보호효과를 확인하였다.

본 연구에서, $40 \%$ 우지가 포함된 고지방을 식이한 랫 드의 체중이 현저하게 증가하였고 다량의 지방조직이 복 부와 부고환 주위로 축적되었다(Table 1, Figures 1A, 1C $\&$ 1D). 당유자 과피를 급여함에 따라 체중 및 지방조직 들의 무게가 감소함을 보여 식이성 비만에 대한 당유자 과피의 개선 효과를 확인할 수 있었고, 또한 사료섭취량 및 사료효율이 고지방식이군과 비교하여 차이가 없었으 므로 당유자 과피의 항비만 효과는 식이 억제와 관련이 없다고 사료된다. Sibutramine은 식이량을 감소시키고 열 발생을 증가시키는 약물로, 비만치료제로 사용되고 있다 (Apfelbaum et al., 1999; Walsh et al., 1999). 본 실험 에서도 sibutramine의 투여에 의한 체중 및 지방조직 무 게의 감소가 사료섭취의 억제로 인한 것으로 확인되었다.
Lavie and Milani (2003)은 비만으로 인해 혈중 지질 중 중성지방을 증가시키고 $\mathrm{HDL}-\mathrm{C}$ 을 감소시킨다고 하였으며, Jayakumar et al. (1991)은 고지방으로 랫드에서 콜레스테 롤의 합성이 증가된다고 보고하였다. 이번 연구에서, 장 기간의 고지방식이 섭취로 인해 혈청 중의 $\mathrm{TG}, \mathrm{TC}$ 및 LDL-C의 함량이 높은 수준으로 나타났다(Figure 2). 그리 고 고지방을 식이한 랫드에 비해 당유자 과피의 급여가 혈청 중 $\mathrm{TG}, \mathrm{TC}, \mathrm{LDL}-\mathrm{C}$ 의 함량을 각각 $30,30,40 \%$ 가량 낮춰주는 효과를 나타내었으며, sibutramine 역시 당 유자 과피와 비슷한 효과를 보여주었다. 반면, $\mathrm{HDL}-\mathrm{C}$ 의 혈청 내 함량은 군간의 차이가 없었다. 고지방식이 유도 비만모델에서 Yang et al. (2007)은 칙피스(chickpeas), $\mathrm{Hsu}$ et al. (2009)은 페놀계 화합물인 rutin과 Ocoumaric acid의 지질개선을 통한 항비만 효과를 규명하 였다. 당유자 과피 역시 고지방식이로 유발되는 고지혈증 또는 고콜레스테롤혈증을 개선시킴으로써 항비만 효과를 나타낸다고 할 수 있다.

간은 콜레스테롤, 인지질(phospholipids), TC, 그리고 지 단백(lipoproteins)의 대사에 중추 역할을 하는 장기이기 때문에, 비만에서 다량의 지방산이 축적되어 지방간을 유 발시킨다(Festi et al., 2004; Hsu and Yen, 2007). 또한 고지방의 식이량이 증가할수록 체내 free radicals의 생성 이 증가하고 이를 방어하는 체내 항산화시스템의 기능 저 하로 지질 과산화물이 체내에 축적되게 된다(Kim et al., 2006). 본 연구에서의 고지방식이에 의한 간조직 내 MDA 생성 및 침착은 당유자 과피의 급여로 인해 유의적으로 억제되었다(Figure 4). 또한 간조직을 $\mathrm{H \& E}$ 염색으로 관찰 한 결과(Figure 6), 고지방식이군의 간 조직에서 간세포의 핵 소실, 지방방울의 과도한 축적을 확인할 수 있었고, 당유자 과피를 급여한 군에서는 지방방울이 거의 관찰되 지 않았으며, 정상군의 간 조직과 유사한 양상을 보였다. 이는 Laurent et al. (2004)과 Pressayre et al. (2004)의 보고에 따라, 당유자 과피의 항산화 작용으로 비만에 의 한 지방간의 형성이 억제되었다고 생각할 수 있다.

비만에 의해 유도되는 고혈압에 대해 당유자 과피의 영 향을 평가하기 위해 수축기 혈압을 측정한 결과, 고지방 식이로 인해 혈압이 $140 \mathrm{mmHg}$ 이상으로 상승하였고, 당 유자 과피 급여군에서는 혈압이 정상 범위인 $116 \mathrm{mmHg}$ 를 유지하였다. 하지만 sibutramine 투여에 의해서는 그 의 부작용이 알려진 바와 같이 비만에 의해 상승된 혈압 을 개선시켜주지 못하였다(Figure 5). 고지방 식이에 의한 고혈압 등의 심혈관계 질환 발생은 혈 중 콜레스테롤과 $\mathrm{LDL}-\mathrm{C}$ 과 TC의 수치가 증가함으로써, 그리고 산화적 스트 레스(oxidative stress)에 의해서도 나타난다(Roberts et al., 2002; Smith et al., 2004). 따라서, 비만에서 당유자 과 피의 항고혈압 효과는 그의 지질개선 효능과 항산화 효 과에 의한 것으로 사료된다. 
이상의 실험결과를 종합해 보면, 감귤류의 당유자는 식 이성 비만 실험동물 모델에서 항비만 및 비만에 의한 고 혈압 발생을 억제할 수 있으며, 이는 당유자의 혈중 지 질 농도 개선 효과로 인한 것임을 알 수 있다. 따라서, 당유자를 활용한 비만 또는 심혈관계 질환의 치료제 또 는 건강기능성 식품 개발이 기대된다.

\section{감사의 글}

본 연구는 농촌진흥청 공동연구사업(과제번호: PJ006723) 의 지원에 의해 이루어진 것 임.

\section{참고문헌}

Apfelbaum, M.D., Vague, P., Ziegler, O., Hanotin, C., Thomas, F. and Leutenegger, E. (1999) Long-term maintenance of weight loss after a very-low-calorie diet a randomized blinded trial of the efficacy and tolerability of sibutramine. Am. J. Med. 106(2), 179-184.

Buege, J.A. and Aust, S.D. (1978) Microsomal lipid peroxidation. Methods Enzymol. 52, 302-310.

Cho, J.H., Lee, N.J., Hong, S.H., Kim, D.K., Shin, S., Park, J.H., Kang, J.K., Kim, Y.B. and Hwang, S.Y. (2005) Effect of HGD201 on obesity induced by high-fat diet in Zucker rats. Lab. Anim. Res. 21(2), 158-163.

Cuevas, P., Garcia-Calvo, M., Carceller, F, Reimers, D., Zazo, M., Buevas, B., Munoz-Willery, I., Martinez-Coso, V., Lamas, S. and Gimenez-Gallego, G. (1996) Correction of hypertension by normalization of endothelial levels of fibroblast growth factor and nitric oxide synthase in spontaneously hypertensive rats. Proc. Natl. Acad. Sci. USA 93(21), 11996-12001.

Festi, D., Colecchia, A., Sacco, T., Bondi, M., Roda, E. and Marchesini, G. (2004) Hepatic steatosis in obese patients: clinical aspects and prognostic significance. Obesity Rev. 5(1), $27-42$.

Fujioka, K., Seaton, T.B., Rowe, E., Jelinek, C.A., Raskin, P., Levovitz, H.E. and Weinstein, S.P. (2000) Weight loss with sibutramine improves glycaemic control and other metabolic parameters in obese patients with type 2 diabetes mellitus. Diabetes Obes. Metab. 2(3), 175-187.

Hill, J.O., Peters, J.C. and Wyatt, H.R. (2007) The role of public policy in treating the epidemic of global obesity. Clin. Pharmacol. Ther. 81(5), 772-775.

Hsu, C.L. and Yen, G.C. (2007) Effect of gallic acid on high fat diet-induced dyslipidaemia, hepatosteatosis and oxidative stress in rats. Br. J. Nutr. 98, 727-735.

Hsu, C.L., Wu, C.H., Huang, S.L. and Yen G.C. (2009) Phenolic compounds rutin and O-coumaric acid ameliorate obesity induced by high-fat diet in rats. J. Agric. Food Chem. 57(2), 425-431.

Jayakumar, S.M., Nalini, N. and Venugopal, P.M. (1991) Effect of ginger (Zingiber officinale) on lipids in rats fed atherogenic diet. J. Clin. Biochem. Nutr. 27(2), 79-82.

Kim, M.H., Jang, S.Y. and Lee, Y.S. (2006) Effect of dietary fat and genistein on lipid metabolism and antioxidant activity in hyperlipidemic male rats induced high fat diet. Korean $\mathrm{J}$. Food Sci. Technol. 39(2), 100-108.

Kim, S.J., Jung, J.Y., Kim, H.W. and Park, T.S. (2008) Anti-obesity effects of Juniperus chinensis extract are associated with increased AMP-activated protein kinase expression and phosphorylation in the visceral adipose tissue of rats. Biol. Pharm. Bull. 31(7), 1415-1421.
Kopelman, P.G. (2000) Obesity as a problem. Nature 404(6778), 635-643.

Laurent, A., Nicco, C., Tran, V.N.J., Borderie, D., Chereau, C., Conti, F., Jaffray, P., Soubrane, O., Calmus, Y., Beill, B. and Batteux, F. (2004) Pivotal role of superoxide anion and beneficial effect of antioxidant molecules in murine steatohepatitis. Hepatology 39(5), 1277-1285.

Lavie, C.J. and Milani, R.V. (2003) Obesity and cardiovascular disease: the Hippocrates paradox? J. Am. Coll. Cardiol. 42(4), 677-679.

Lee, H.J., Kang, G.J., Yoon, W.J., Kang, H.K., Kim, Y.S., Kim, S.M. and Yoo, E.S. (2006) Anti-inflammatory effect of Unripe fruit of Citrus grandis Osbeck in RAW264.7 and HaCaT cells. Kor. J. Pharmacogn. 37(2), 74-80.

Lim, H.K., Yoo, E.S., Moon, J.Y., Jeon, Y.J. and Cho, S.M.K. (2006) Antioxidant activity of extracts from Dangyuja (Citrus grandis Osbeck) fruits produced in Jeju island. Food Sci. Biotechnol. 15(2), 312-316.

Leung, W.Y.S., Thomas, G.N., Chan, J.C.N. and Tomlinson, B. (2003) Weight management and current options in pharmacotherapy: Orlistat and sibutramine. Clin. Ther. 25(1), 58-80.

McMahon, F.G., Fujioka, K., Singh, B.N, Mendel, C.M., Rowe, E., Rolston, K., Johnson, F. and Mooradian, A.D. (2000) Efficacy and safety of sibtramine in obese white and African American patients with hypertension: a 1-year, double-blind, placebo-controlled, multicenter trial. Arch. Intern. Med. 160(14), 2185-2191.

Moon, J.Y., Kim, H.N., Cho, M.J., Chang, W.Y., Kim, C.T. and Cho, S.M.K. (2009) Induction of apoptosis in SNU-16 human gastric cancer cells by the chloroform fraction of an extract of Dangyuja (Citrus grandis) leaves. J. Korean Soc. Appl. Biol. Chem. 52(2), 168-175.

Nakayama, T., Suzuki, S., Kudo, H., Sassa, S., Nomura, M. and Sakamoto, S. (2007) Effects of three Chinese herbal medicines on plasma and liver lipids in mice fed a high-fat diet. J. Ethnopharmacol. 109, 236-240.

Park, S.H., Ko, S.K. and Chung, S.H. (2005) Euonymus alatus prevents the hyperglycemia and hyperlipidemia induced by high-fat diet in ICR mice. J. Ethnopharmacol. 102, 326-335.

Pessayre, D., Fromenty, B. and Mansouri, A. (2004) Mitochondrial injury in steatohepatitis. Eur. J. Gastroenterol. Hepatol. 16(11), 1095-1105.

Roberts, C.K., Vaziri, N.D., Ni, Z. and Barnard, R.J. (2002) Correction of long-term diet-induced hypertension and nitrotyrosine accumulation by diet modification. Atherosclerosis 163(2), 321-327.

Smith Jr, S.C., Jackson, R., Pearson, T.A., Fuster, V., Yusuf, S., Faergeman, O., Wood, D.A., Alderman, M., Horgan, J., Home, P., Hunn, M. and Grundy, S.M. (2004) Principles for national and regional guidelines on cardiovascular disease prevention: a scientific statement from the World Heart and Stroke Forum, Circulation 109(25), 3112-3121.

Song, E.Y., Choi, Y.H., Kang, K.H. and Koh, J.S. (1998) Free sugar, organic acid, hesperidin, naringin and inorganic elements changes of cheju citrus fruits according to harvest dat. Korean J. Food Sci. Technol. 30(2), 306-312.

Vasselli, J.R. and Weindruch, R. (2005) Intentional weight loss reduces mortality rate in a rodent model of dietary obesity. Obesity Res. 13(4), 693-702.

Walsh, K.M., Leen, E. and Leen, M.E. (1999) The effect of sibutramine on resting energy expenditure and adrenalineinduced thermogenesis in obese females. Int. J. Obes. Relat. Metab. Disord. 23(10), 1009-1015.

Yang, Y., Zhou, L., Gu, Y., Zhang, Y., Tang, J., Li, F., Shang, W., Jiang, B., Yue, X. and Chen, M. (2007) Dietary chickpeas reverse visceral adiposity, dyslipidemia and insulin resistance in rats induced by a chronic high-fat diet. Br. J. Nutr. 98(4), 720-726. 